\title{
Effect of irrigation water on the incidence of Salmonella spp. on lettuces produced by urban agriculture and sold on the markets in Dakar, Senegal
}

\author{
M. L. Ndiaye ${ }^{1,5 *}$, Y. Dieng ${ }^{2}$, S. Niang ${ }^{1}$, H. R. Pfeifer ${ }^{3}$, M. Tonolla ${ }^{4}$ and R. Peduzzi ${ }^{5,6}$ \\ ${ }^{1}$ LATEU-Laboratoire de traitement des eaux usées- IFAN- Université Cheikh A. Diop, Dakar, Sénégal. \\ ${ }^{2}$ Département de parasitologie et mycologie, Université Cheikh A. Diop Dakar, Sénégal. \\ ${ }^{3}$ IMG-Centre d'Analyse Minérale, Faculté de Géosciences et de l'Environnement, Bâtiment Anthropole, \\ $\mathrm{CH}-1015$ Lausanne, Switzerland. \\ ${ }^{4}$ Cantonal Institute of Microbiology, via Mirasole 22A, CH-6500 Bellinzona, Switzerland. \\ ${ }^{5}$ Laboratory of Microbial Ecology, Microbiology Unit, Plant Biology Department, University of Geneva, Switzerland. \\ ${ }^{6}$ Alpine Biology Center Foundation, Piora, CH-6777 Quinto, Switzerland.
}

Accepted 22 August, 2011

\begin{abstract}
The aim of our survey was to assess the effect of irrigation water of the microbiological quality on the production chain of lettuce in the Dakar area. Microbiological analysis showed that $35 \%$ of irrigation water was contaminated by Salmonella spp. between the two water-types used for irrigation (groundwater and wastewater), no significant difference $(p>0.05)$ in their degree of contamination was found. The incidence of different types of irrigation water on the contamination rate of lettuces from the farm (Pikine and Patte d'Oie) was not different either ( $p>0.05)$. However, the contamination rate of lettuce from markets of Dalifort and Grand-Yoff that were supplied by the area of Patte d'Oie was greater than those of Sham and Zinc supplied by Pikine $(p<0.05)$. Comparison of serotypes of Salmonella isolated from irrigation water and lettuce showed that irrigation water may affect the microbiological quality of lettuce. Manures, frequently used as organic amendment in cultivating lettuce are another potential source of contamination. These results showed that lettuce may constitute effective vectors for the transmission of pathogens to consumers. Extensive treatment of the used wastewater and/or composting of manure could considerably reduce these risks.
\end{abstract}

Key words: Urban agriculture, Dakar, irrigation water, Salmonella spp., lettuce, manure.

\section{INTRODUCTION}

Foodborne illnesses caused by pathogenic bacteria still occur at unacceptable high frequencies in industrialized nations and developing countries (Lampel et al., 2000). The increasing occurrence of foodborne diseases during the last decades seems to be related to the presence of

\footnotetext{
*Corresponding author. E-mail: ndiayeml@gmail.com.
}

Abbreviations: FAO, Food and agriculture organization; NACMCF, national advisory committee on microbiological criteria for foods; UA, urban agriculture; PE, polyethylene; T, tonne; FISH, fluorescence in situ hybridization. microorganisms in food (FAO, 2004). According to Sivapalasingam et al. (2004), the proportion of foodborne illness has increased from 0.7 to $6 \%$ between 1970 and 1990. In Africa, over 30,000 children die each year due to the consumption of contaminated food (Mensah, 2005). Fresh fruits and vegetables are increasingly recognized as potential sources of diseases (Beuchat, 2002; lbenyassine et al., 2006; NACMCF, 1999). Fresh vegetables are among the products associated to foodborne disease outbreaks in the Unites States (Sivapalasingam et al., 2004). Vegetables can become contaminated by pathogens while growing, during harvest, by post-harvest handling, or distribution 


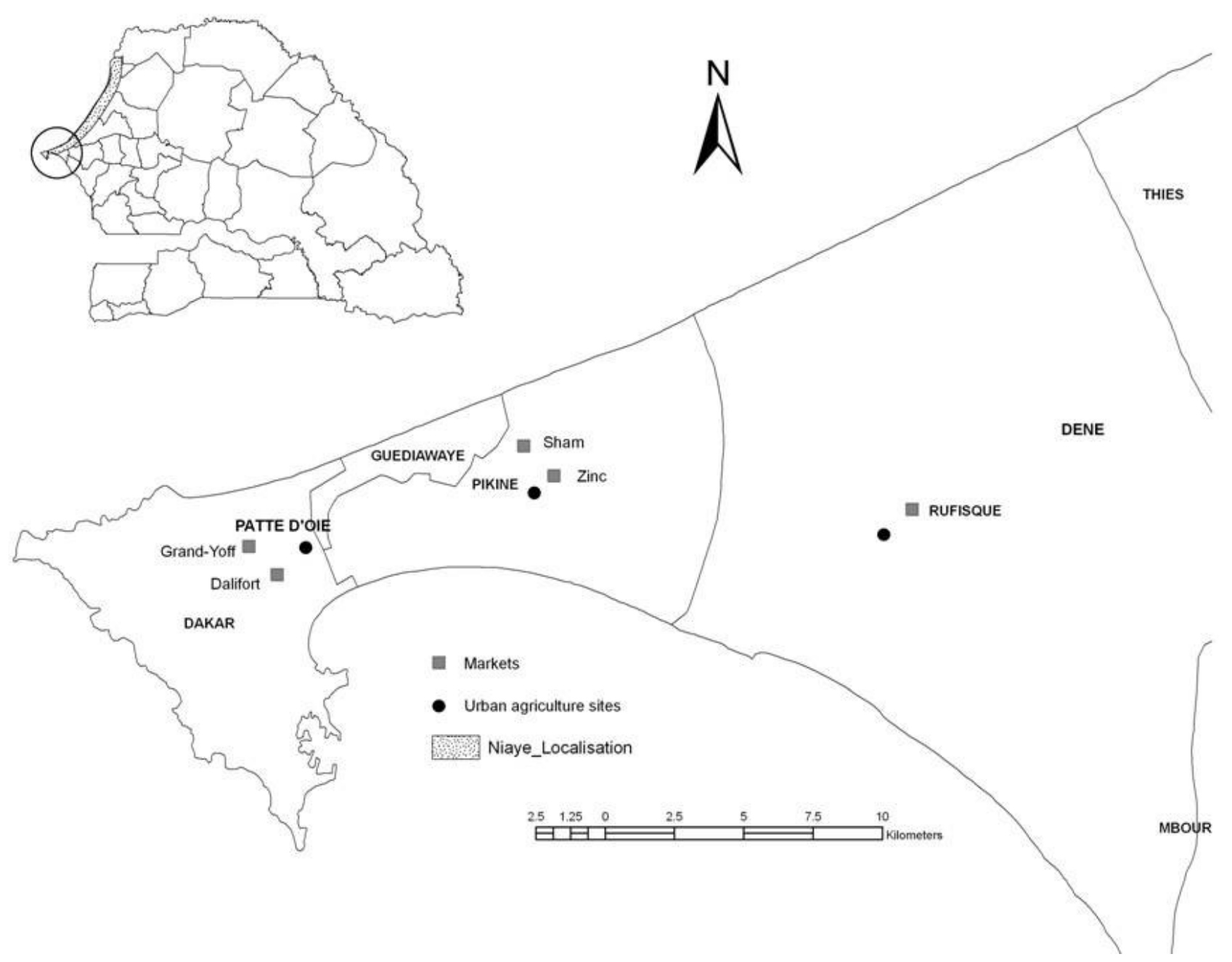

Figure 1. Maps showing the studied urban agriculture sites and markets.

(McMahon and Wilson, 2001). Numerous studies have shown that vegetables from fields irrigated with polluted water and amended with manure are contaminated (AlLahham et al., 2003; Amoah et al., 2005; Ibenyassine et al., 2006; Rosas et al., 1984).

\section{Study background}

Senegal, like most developing countries, is facing demographic expansion. The capital Dakar hosts one fifth of the population on an area of $0.28 \%$ of the national territory. During the last ten years, urban agriculture has played an increasingly important role in food security control, assuring more than $70 \%$ of the vegetable supply in Dakar (Mbaye, 1999). However, increasing water scarcity and the poor agronomic value of shallow well water ('Céanes'), are at the origin of the frequent use of wastewater and animal manures, such as poultry or horse droppings, in urban agriculture. Therefore, sanitary risks related to the consumption of fresh vegetables from urban agriculture have become an important issue. In fact, the use of wastewater is believed to have contributed to cholera epidemics and typhoid occurring in Senegal during the last decades (Gaye and Niang, 2002). In that regard, it is important to assess the microbiological quality of vegetables (especially raw vegetables) for the whole process chain, that is from the production to market sale, and to determine the sources of contamination, in order to propose alternatives to prevent consumers from disease outbreaks.

\section{MATERIALS AND METHODS}

\section{Sampling of the irrigation water}

Our survey took place in the two areas of urban agriculture (UA) of Pikine and Patte d'Oie in Dakar (Figure 1 and Table 1). In 2008, six field experiments were carried out. 78 samples of three types of irrigation water, that is wastewater, shallow groundwater ("Céanes") 
Table 1. Characteristics of the studied urban agriculture sites and their water source.

\begin{tabular}{lcc}
\hline \multirow{2}{*}{ Characteristic } & \multicolumn{2}{c}{ Study site } \\
\cline { 2 - 3 } & Pikine & Patte d'Oie \\
\hline Irrigated area (ha) & 49.9 & 12 \\
Annual lettuce yield (T/year) & 3544 & 560 \\
Number of farmers & 830 & 161 \\
Water source for irrigation & Wastewater, shallow groundwater & Wastewater $^{1}$, shallow groundwater, well water \\
\hline
\end{tabular}

${ }^{1}$ Wastewater was forbidden since May 2008.

and normal well water have been sampled. For each type, one litre has been collected in a sterile polyethylene (PE) bottle, and placed in an icebox at $4{ }^{\circ} \mathrm{C}$ for microbiological analysis in the laboratory.

\section{Lettuce sampling}

Lettuce sampling in the field was based on 17 and 25 plots respectively in Pikine and Patte d'Oie, with various types of irrigation water. In each plot, three mature lettuce plants were taken (in certain cases less than 3 , depending on the farmer found in place). In total, 123 samples were taken. The lettuces were put in separate and sterile plastic bags, and then placed in an icebox containing freezer packs for the conservation at $4^{\circ} \mathrm{C}$ during transport to the laboratory. Sampling was accompanied by an inquiry upon farmers.

For the sampling on the markets, the choice of the studied markets was made based on the results of an earlier investigation to identify the most important selling points of vegetables produced in the two studied UA areas (Ndiaye, 2009). For Pikine, the Zinc and Sham markets were selected, and for Patte d'Oie, the markets of Grand-Yoff and Dalifort (Figure 1). In each market, three lettuce plants were taken per saleswoman. Conditioning was made as for those sampled in the plots. In total, 205 samples were collected and analysed. As in the UA areas, sampling was accompanied by inquiry upon the saleswomen (13 to 20 according to the market, in total 88)

\section{Analyses}

For Salmonella spp. analysis of irrigation water, $500 \mathrm{ml}$ of were filtred through an acetate cellulose filter with $0.45 \mu \mathrm{m}$ pore size (for wastewater $\sim 10 \mathrm{ml}$ because of clogging). The filter was then transferred in a test tube containing $9 \mathrm{ml}$ Rappaport Vasilliadis R10 Broth and incubated at $43^{\circ} \mathrm{C}$ during $24 \mathrm{~h} .100 \mu \mathrm{l}$ of the mixture were inoculated on the Hecktoen medium and incubated at $43^{\circ} \mathrm{C}$ for 24 h. Suspect colonies were re-suspended in $1 \mathrm{~mL}$ of physiological water $(9 \% \mathrm{NaCl})$. Biochemical tests were performed using Kligler Hajna, Citrate of Simmons, Mannitol-mobility, urea/indole media and ONPG (o-nitrophényl- $\beta$-D-galactopyranoside).

Confirmation for the presence of microbial cells belonging to Salmonella in the original sample was performed by the FISH method (Amann et al., 1990) using the Sal3 probe (Nordentoft et al., 1997) labelled with Cy3 dye. Serotyping of Samonella spp. was performed using the agglutination method with antiserum for Salmonella on a glass slide. The strains that could not be identified were serotyped by the « Nationales Zentrum für enteropathogene Bakterien » of Luzern (Switzerland).

To assess the microbiological quality of lettuces, $10 \mathrm{~g}$ of fresh material were weighed and put into a sterile Stomacher bag, containing $90 \mathrm{~mL}$ of Rappaport Vasilliadis R10 Broth. After homogenization with a Stomacher mixer at $200 \mathrm{rpm}$ during $5 \mathrm{~s}$, the bag was incubated at $43^{\circ} \mathrm{C}$ during $24 \mathrm{~h}$. Analysis of Salmonella spp. was performed in the same manner as for irrigation water.

The resulting data were analysed using the statistical software SPSS for Windows 17.0. Chi-square tests $(X 2)$ were performed to evaluate statistical difference of the data and the results are quoted at $p<0.05$ levels of significance.

\section{RESULTS AND DISCUSSION}

\section{Salmonella spp. from irrigation water}

Salmonella spp. has been isolated in $35 \%$ of the irrigation water analyzed. The difference in the rate of contamination between natural water (Céanes and well water, $40 \%)$ and wastewater (19\%) was not significant ( $p>0.05)$. In Pikine, the rate of contamination of Céanes water was $33 \%$ and for the wastewater $22 \%$ (Table 2). In Patte d'Oie, more than half of Céane waters $(57 \%)$ analyzed contained Salmonella spp. and $27 \%$ of well waters. Wastewater was found Salmonella-free. These results seem paradoxical, that is that Céanes and well water (local groundwater) are too contaminated than wastewater $(p>0.05)$. A recent study on these two sites showed that the use of manure as fertilizer was systematic whatever the type of irrigation water (Ndiaye, 2009). However, plots irrigated with Céane and well water received important amounts of manure because of the water's low-nutrients quality for plants. A comparison of Salmonella serotypes from Céanes water used as irrigation water at Pikine and Patte d'Oie (S. Chester, $S$. Virchow, $S$. Corvallis, $S$. Give) to those that can be found in animals manure (poultry, horses) suggested a contamination of the shallow groundwater by manure spread on fields (Table 3). Indeed, the stagnant shallow groundwater of the "Céanes" had high loads of faecal bacteria due to the fact that farmers often walk in them to fill their watering cans, after having walked over their plots treated with animal manure (Ndiaye et al., 2010). In the same manner, runoff can also contribute an important part. According to Amoah et al. (2005), the shallow wells used in urban agriculture in Kumasi (Ghana) are contaminated because they are not protected against runoff. Another important source of contamination was the washing of lettuce in the Céanes by saleswomen to remove sands from roots after harvest. The excessive 
Table 2. Contamination of irrigation water for Salmonella spp.

\begin{tabular}{lcc}
\hline \multirow{2}{*}{ Type of irrigation water } & \multicolumn{2}{c}{ Study site } \\
\cline { 2 - 3 } & Pikine & Patte d'oie \\
\hline Shallow groundwater "Céanes" (\%) & $\mathrm{n}^{1}=18(33)$ & $\mathrm{n}=21(57)$ \\
Wastewater (\%) & $\mathrm{n}=18(22)$ & $\mathrm{n}=3(0)$ \\
Well water (\%) & - & $\mathrm{n}=18(27)$ \\
\hline
\end{tabular}

${ }^{1}$ Number of samples analysed.

Table 3. Serotype of Salmonella isolated from irrigation water.

\begin{tabular}{|c|c|c|c|c|c|}
\hline \multirow{2}{*}{ Type } & \multirow{2}{*}{ Group } & \multirow{2}{*}{ Somatic (0) Antigen } & \multicolumn{2}{|c|}{ Flagellar (H) Antigen } & \multirow{2}{*}{ Detected in the animals ${ }^{\star \star}$} \\
\hline & & & Phase 1 & Phase 2 & \\
\hline S. Paratyphi $A^{2, a}$ & $A$ & $1,2,12$ & $\mathrm{a}$ & {$[1,5]$} & \\
\hline S. Chester ${ }^{1, a ; 1, b}$ & $\mathrm{~B}$ & $\underline{1}, 4,[5], 12$ & $e, h$ & $e, n, x$ & Po, Sh \\
\hline S. Kunduchi ${ }^{2, a ; 3, b}$ & & $1,4,[5], 12, \underline{27}$ & $\mathrm{i}, \mathrm{z}_{28}$ & 1, 2 & \\
\hline S. Kimuenza ${ }^{2, a}$ & & $1,4,12, \underline{27}$ & $\mathrm{I}, \mathrm{v}$ & $e, n, x$ & \\
\hline S. Kingston ${ }^{3, b}$ & & $1,4,[5], 12, \underline{27}$ & $\mathrm{~g}, \mathrm{~s}, \mathrm{t}$ & 1,2 & \\
\hline S. Lomita ${ }^{1, b}$ & $\mathrm{C}_{1}$ & 6,7 & $\mathrm{e}, \mathrm{h}$ & 1,5 & \\
\hline S. Arizonae ${ }^{1, b}$ & & 6,7 & $\mathrm{I}, \mathrm{v}$ & $\mathrm{z}_{53}$ & \\
\hline S. Montevideo ${ }^{3, \mathrm{~b}}$ & & 6,7 & $\mathrm{~g}, \mathrm{~m},[\mathrm{p}], \mathrm{s}$ & - & \\
\hline S. Bonn ${ }^{1, \mathrm{a}}$ & & 6,7 & $\mathrm{I}, \mathrm{v}$ & $e, n, x$ & \\
\hline S. Virchow ${ }^{1, \mathrm{~b},{ }^{*}}$ & & 6,7 & $r$ & 1,2 & Po, B, Sh, Go \\
\hline S. Colindale ${ }^{2, a,{ }^{*}}$ & & 6,7 & r & 1,7 & \\
\hline S. Manchester ${ }^{2, a ; 1, b}$ & $\mathrm{C}_{2}$ & 6,8 & $\mathrm{I}, \mathrm{v}$ & 1,7 & \\
\hline S. Corvallis ${ }^{1, a ; 1, b,{ }^{*}}$ & $\mathrm{C}_{3}$ & $8, \underline{20}$ & $\mathrm{z}_{4}, \mathrm{z}_{23}$ & - & $\mathrm{H}, \mathrm{B}, \mathrm{Go}$ \\
\hline S. Molade ${ }^{3, b, *}$ & & $8, \overline{20}$ & $z_{10}$ & $z_{6}$ & \\
\hline S. Typhi ${ }^{1, b}$ & $\mathrm{D}_{1}$ & $9,12,[\mathrm{Vi}]$ & $d$ & - & \\
\hline S. Javiana ${ }^{3, b}$ & & $\underline{1}, 9,12$ & $\mathrm{I}, \mathrm{Z}_{28}$ & 1,5 & \\
\hline Salmonella ${ }^{1, a}$ & & 9,12 & $e, n, x$ & 1,6 & \\
\hline S. Give $e^{1, a}$ & $\mathrm{E}_{1}$ & 3,10 & $\mathrm{I}, \mathrm{v}$ & 1,7 & B, Sh \\
\hline S. Muenster ${ }^{1, \mathrm{a}}$ & & 3,10 & $e, h$ & 1,5 & H, B, Sh, Go \\
\hline S. Stendal $\left.\right|^{2, a ; 1, b}$ & $\mathrm{~F}$ & 11 & $\mathrm{I}, \mathrm{v}$ & 1,2 & \\
\hline S. Maracaibo ${ }^{1, b}$ & & 11 & $\mathrm{I}, \mathrm{v}$ & 1,5 & B \\
\hline S. Marseille ${ }^{2, \mathrm{~b},{ }^{*}}$ & & 11 & $a$ & 1,5 & \\
\hline S. Tilène $e^{3, b,{ }^{*}}$ & $\mathrm{R}$ & $\underline{1}, 40$ & $e, h$ & 1,2 & $\mathrm{~B}, \mathrm{Sh}$ \\
\hline S. Teshie ${ }^{1, \mathrm{a},{ }^{\star}}$ & $x$ & 1,47 & $\mathrm{I}, \mathrm{z}_{13}, \mathrm{z}_{28}$ & $e, n, x$ & \\
\hline S. Dougi ${ }^{2, \mathrm{a} ; 1, \mathrm{~b},{ }^{*}}$ & Z & 50 & $y$ & 1,6 & \\
\hline S. Aarhus ${ }^{1, b,{ }^{*}}$ & & & & & \\
\hline
\end{tabular}

${ }^{1}$ Shallow groundwater water; ${ }^{2}$ Wastewater; ${ }^{3}$ Well water; ${ }^{a}$ Site of Pikine; ${ }^{\mathrm{b}}$ Site of Patte d'Oie

* Species are serotyped by the Nationales Zentrum für enteropathogene Bakterien, Luzern (Switzerland)

** Species isolated from $\mathrm{Po}=$ Poultry, $\mathrm{Sh}=\mathrm{Sheep}, \mathrm{B}=\mathrm{Beef}, \mathrm{Goat}=\mathrm{Go} ; \mathrm{H}=$ Horse in Senegal. Source (Doutre and Buisson, 1984)

use of poultry manure as fertilizers (100 and $70 \%$ of plots irrigated with Céanes and well water at Patte d'Oie site, respectively) seems to be the cause of the contamination of Céane and well waters. In fact, several authors have shown that poultry manure is a reservoir of Salmonella (Himathongkham et al., 1999; Orji et al., 2005), which can survive for a long time in the soil amended with such type of manure (Islam et al., 2004).

Pathogens such as $S$. Paratyphi A and $S$. Typhi were isolated from wastewater from Pikine and Céanes water from Patte d'Oie, respectively.

\section{Salmonella in lettuce}

The difference between contamination rates of lettuce from Pikine $(6 \%)$ and Patte d'Oie (7\%) was not significant (Table 4). The method of irrigation (watering cans) used 
Table 4. Rate of contamination of lettuce from the fields and markets.

\begin{tabular}{llcccc}
\hline Location & Origin & $\mathbf{n}^{\star}$ & \% of positive samples & $\mathbf{X}^{2}$ & $\mathbf{P}^{\star \star}$ \\
\hline \multirow{2}{*}{ On-farm lettuce } & Pikine & 53 & 6 & 0.08 & 0.77 \\
& Patte d'Oie & 72 & 7 & & \\
& & & & & \\
\multirow{2}{*}{ Lettuce from markets } & Pikine (Sham and Zinc markets) & 99 & 3 & 4.34 & 0.03 \\
\cline { 2 - 5 }
\end{tabular}

${ }^{*}$ Number of samples. ${ }^{*} \mathrm{P}$-value: significant if $\mathrm{p}<0.05$.

Table 5. Serotype of Salmonella isolated from on-farm lettuce and those from markets.

\begin{tabular}{|c|c|c|c|c|c|}
\hline \multirow{2}{*}{ Type } & \multirow{2}{*}{ Group } & \multirow{2}{*}{$\begin{array}{l}\text { Somatic (0) } \\
\text { Antigen }\end{array}$} & \multicolumn{2}{|c|}{ Flagellar (H) Antigen } & \multirow{2}{*}{$\begin{array}{l}\text { Detected in the animals and/o } \\
\text { irrigation water }\end{array}$} \\
\hline & & & Phase 1 & Phase 2 & \\
\hline S. Kunduchi ${ }^{2}$ & $B$ & $\underline{1}, 4,[5], 12, \underline{27}$ & $\mathrm{i}, \mathrm{z}_{28}$ & 1,2 & $\S$ \\
\hline S. Caledon ${ }^{3}$ & & 4,12 & $\mathrm{~g}, \mathrm{~m}, \mathrm{t}$ & {$[e, n, x]$} & \\
\hline S. Kingston ${ }^{4}$ & & $1,4,[5], 12, \underline{27}$ & $g, s, t$ & 1,2 & $\psi$ \\
\hline S. Schwarzengrund ${ }^{\mathrm{a}, *}$ & & $1,4,12, \underline{27}$ & $d$ & 1,7 & \\
\hline S. Banana ${ }^{3, *}$ & & $4, \underline{5}, 12$ & $\mathrm{~m}, \mathrm{t}$ & - & \\
\hline S. Montevideo ${ }^{3,4}$ & $\mathrm{C}_{1}$ & 6,7 & $g, m,[p], s$ & - & $\mathrm{H}, \mathrm{B}, \mathrm{Go}, \Psi$ \\
\hline S. Mbandaka ${ }^{\mathrm{a},}$ & & $6,7, \underline{N}$ & $z_{10}$ & $e, n, z_{15}$ & Po \\
\hline S. Manchester ${ }^{3}$ & $\mathrm{C}_{2}$ & 6,8 & $\mathrm{l}, \mathrm{v}$ & 1,7 & $\psi$ \\
\hline S. Molade ${ }^{\mathrm{b}}$ & $\mathrm{C}_{3}$ & 8,20 & $z_{10}$ & $\mathrm{z}_{6}$ & $\S, \Psi$ \\
\hline Salmonella ${ }^{\mathrm{a}, 1}$ & $D_{1}$ & 9,12 & $e, n, x$ & 1,6 & $\S$ \\
\hline S. Ekotedo ${ }^{1},{ }^{*}$ & $D_{2}$ & 9,46 & $\mathrm{Z}_{4}, \mathrm{Z}_{23}$ & - & \\
\hline S. Sinstorf ${ }^{3}$ & $E_{1}$ & 3,10 & $\mathrm{I}, \mathrm{v}$ & 1,5 & \\
\hline S. Westhampton ${ }^{\mathrm{b}}$ & & 3,10 & $g, s, t$ & - & \\
\hline S. New-haw ${ }^{4}$ & $\mathrm{E}_{2}$ & $3, \underline{15}$ & $\mathrm{e}, \mathrm{h}$ & 1,5 & \\
\hline S. Gaminara ${ }^{2},{ }^{*}$ & I & 16 & $d$ & 1,7 & $\mathrm{H}, \mathrm{Go}$ \\
\hline S. Tilène $e^{4, *}$ & $\mathrm{R}$ & 1,40 & $e, h$ & 1,2 & $\mathrm{~B}, \mathrm{Sh}, \Psi$ \\
\hline
\end{tabular}

a Site of Pikine; ${ }^{b}$ Site of Patte d'Oie. ${ }^{1}$ Zinc, ${ }^{2}$ Sham, ${ }^{3}$ Grand-Yoff, ${ }^{4}$ Dalifort. * Species are serotyped by the Nationales Zentrum für enteropathogene Bakterien, Luzern (Switzerland). ${ }^{* *}$ Species isolated from $\mathrm{Po}=$ Poultry, Sh=Sheep, B= Beef, Go= Goat; H=Horse in Senegal. Source (Doutre and Buisson, 1984). $\S$ Serotype isolated in irrigation water from Pikine. $\Psi$ Serotype isolated in irrigation water from Patte d'Oie

in both UA sites plays an important role in the contamination of lettuce. Studies on the effect of irrigation methods on the contamination level of vegetable have shown that even for strongly contaminated irrigation water, drip or furrow methods substantially reduced the risk of crop contamination (Ensink et al., 2007; Keraita et al., 2007). According to Rosas et al. (1984), the contamination level of lettuce, compared to other type of vegetable, is due to its small size which promotes the deposition of soil bacteria and manure under the effect of watering or other mechanisms. Moreover, the serotype of Salmonella isolated from irrigation water (that is $S$. Salmonella in Pikine, $S$. Molade in Patte d'Oie), which have been found in lettuce from Pikine and Patte d'Oie, respectively, suggested that the quality of the irrigation water had indeed an impact on the lettuce produced (Table 5). In addition, manure used as fertilizers could affect the quality of lettuce since $S$. Mbandaka which can be isolated from poultry (Doutre and Buisson, 1984) was found on lettuce (Table 5). Manure pathogens can be transferred to the surface of vegetables through conta-minated soils (Islam et al., 2004; Natvig et al., 2002). According to Islam et al. (2004), survival profiles of Salmonella on vegetables and soil samples contaminated by irrigation water were similar to those observed when contamination occurred through compost.

Lettuces from Grand-Yoff and Dalifort markets (from Patte d'Oie) were more contaminated by Salmonella spp. than those from Zinc and Sham markets (from Pikine) $(p<0.05$, Table 4). Serotypes isolated in lettuce from Zinc markets (S. Salmonella), Sham (S. Kenduchy, $S$. Gaminara), Grand-Yoff (S. Montevideo, S. Manchester) and Dalifort ( $S$. Montevideo, S. Kingston, $S$. Tilène) are either present in irrigation water and can be found in manure (Table 5). Numerous studies have shown that pathogenic bacteria such as $S$. Typhimurium could 
survive on lettuce during growth until harvest (Ercolani, 1976; Islam et al., 2004). According to Pescod (1992), Salmonella spp. can survive on fresh vegetables up to 30 days.

\section{Conclusion}

Results of our survey showed that the use of the contaminated local groundwater (Céanes and well water) and wastewater as irrigation water is a greater risk for vegetable contamination.

The presence of Salmonella spp. in lettuce shows that they can be an important vector for the transmission of pathogenic bacteria to consumers. Therefore, an adequate training for farmers and saleswomen may have a positive impact and reduce contamination. Similary, awareness among consumers about the need of disinfection of vegetables eaten raw is essential. The use of wastewater for irrigation, at least treated by lagooning before its use, may be an attractive alternative to groundwater because it would allow reducing the amount of manure used, which seems to be the main source of the microbiological contamination.

The method of irrigation (watering cans) plays an important role in the contamination of lettuce. Therefore the use of other methods like drip or furrow irrigation can considerably reduce the risk of crops contamination.

\section{ACKNOWLEDGMENTS}

This work has been supported by an ECOPOLIS $N^{\circ} 103710-99906060-004$ scholarship of the Canadian Research Centre for International Development (CRDIOttawa) and the Swiss National Science Foundation, Project no. 207021-109689.

\section{REFERENCES}

Al-Lahham O, El Assi NM, Fayyad M (2003). Impact of treated wastewater irrigation on quality attributes and contamination of tomato fruit. Agric. Water Manage., 61(1): 51-62.

Amann RI, Krumholz L, Stahl DA (1990). Fluorescent-oligo-nucleotide probing of whole cells for determinative, phylogenetic, and environmental studies in microbiology. J. Bacteriol., 172(2): 762-770.

Amoah P, Drechsel P, Abaidoo RC (2005). Irrigated urban vegetable production in Ghana: sources of pathogen contamination and health risk elimination. Irrig. Drainage, 54(S1): S49-S61.

Beuchat LR (2002). Ecological factors influencing survival and growth of human pathogens on raw fruits and vegetables. Microbes Infect., 4(4): 413-423.

Doutre MP, Buisson Y (1984). Sérotypes de Salmonella isolés chez l'animal au Sénégal. Rev. Elev. Méd. vét. Pays Trop., 37(2): 123-128.

Ensink JHJ, Mahmood T, Dalsgaard A (2007). Wastewater-irrigated vegetables: market handling versus irrigation water quality. Trop. Med. Int. Health, 12 (s2): 2-7.

Ercolani GL (1976). Bacteriological quality assessment of fresh marketed lettuce and fennel. Appl. Environ. Microbiol., 31 (6): 847852.

FAO (2004). Caractérisation des dangers liés à la présence de pathogènes dans les aliments et dans l'eau. Série évaluation des risques microbiologiques. $\mathrm{FAO}$. Report $\mathrm{N}^{\circ} 3$. Rome, Italie. pp. 85.

Gaye M, Niang S (2002). Epuration extensive des eaux usées pour leur réutilisation dans l'agriculture urbaine : des technologies appropriées en zone sahélienne pour la lutte contre la pauvreté. Etudes et recherches 225-226-227, ENDA., Dakar.

Himathongkham S, Nuanualsuwan S, Riemann H (1999). Survival of Salmonella enteritidis and Salmonella typhimurium in chicken manure at different levels of water activity. FEMS Microbiol. Lett., 172(2): 159-163.

Ibenyassine K, AitMhand R, Karamoko Y, Cohen N, Ennaji MM (2006). Use of repetitive DNA sequences to determine the persistence of enteropathogenic Escherichia coli in vegetables and in soil grown in fields treated with contaminated irrigation water. Lett. Appl. Microbiol., 43(5): 528-533.

Islam M, Morgan J, Doyle MP, Phatak SC, Millner P, Jiang X (2004). Fate of Salmonella enterica Serovar Typhimurium on Carrots and Radishes Grown in Fields Treated with Contaminated Manure Composts or Irrigation Water. Appl. Environ. Microbiol., 70 (4): 2497-2502.

Keraita B, Konradsen F, Drechsel P, Abaidoo RC (2007). Effect of lowcost irrigation methods on microbial contamination of lettuce irrigated with untreated wastewater. Trop. Med. Int. Health, 12 (s2): 15-22.

Lampel KA, Orlandi PA, Kornegay L (2000). Improved Template Preparation for PCR-Based Assays for Detection of Food-Borne Bacterial Pathogens. 10.1128/AEM.66.10.4539-4542.2000. Appl. Environ. Microbiol., 66(10): 4539-4542.

Mbaye A (1999). Production des légumes à Dakar: importance, contraintes et potentialités. In Agriculture urbaine en Afrique de L'ouest, ed. Smith O. International Developement research Centre. OHawa, pp. 56-66.

McMahon MAS, Wilson IG (2001). The occurrence of enteric pathogens and Aeromonas species in organic vegetables. Int. J. Food Microbiol., 70 (1-2): 155-162.

Mensah P (2005). Surveillance et suivi des maladies d'origine alimentaire dans le contrôle alimentaire. WHO-Bureau régional pour l'Afrique.

ftp://ftp.fao.org/es/esn/food/meetings/2005/italy_pres6_fr.pdf. Last access 12.12.2009.

NACMCF (1999). National Advisory Committee on Microbiological Criteria for Foods. Microbiological safety evaluations and recommendations on fresh produce. Food Control, 10(2): 117-143.

Natvig EE, Ingham SC, Ingham BH, Cooperband LR, Roper TR (2002). Salmonella enterica Serovar Typhimurium and Escherichia coli Contamination of Root and Leaf Vegetables Grown in Soils with Incorporated Bovine Manure. Appl. Environ. Microbiol., 68(6): 27372744.

Ndiaye ML (2009). Impacts sanitaires des eaux d'arrosage de l'agriculture urbaine de Dakar (Sénégal). Thèse de doctorat $N^{\circ} 4110$. Faculté des sciences. Université de Genève. pp. 163.

Ndiaye ML, Niang S, Pfeifer HR, Peduzzi R, Tonolla M, Dieng Y (2010). Effect of irrigation water and processing on the microbial quality of lettuces produced and sold on markets in Dakar (Senegal). Irrigation and Drainage: 10.1002 /ird.590.

Nordentoft S, Christensen H, Wegener H (1997). Evaluation of a fluorescence-labelled oligonucleotide probe targeting 23S rRNA for in situ detection of Salmonella serovars in paraffin- embedded tissue sections and their rapid identification in bacterial smears. J. Clin. Microbiol., 35(10): 2642-2648.

Orji MU, Onuigbo HC, Mbata IT (2005). Isolation of Salmonella from poultry droppings and other environmental sources in Awka, Nigeria. Official publication of the International Society for Infectious Diseases : Int. J. infect. Dis., 9(2): 86-89.

Pescod MD (1992). Wastewater treatment and use in agriculture. Food and Agriculture Organization, Rome.

Rosas I, Baez A and Coutino M (1984). Bacteriological quality of crops irrigated with wastewater in the Xochimilco plots, Mexico City, Mexico. Appl. Environ. Microbiol., 47(5): 1074-1079.

Sivapalasingam S, Friedman CR, Cohen L, Tauxe RV (2004). Fresh produce: a growing cause of outbreaks of foodborne illness in 
the United States, 1973 through 1997. J. Food Prot., 67(10): 23422353. 